\title{
Sociological insights on residential tourism: host society attitudes in a mature destination
}

\author{
Alejandro Mantecón ${ }^{1 *}$ and Raquel Huete ${ }^{2}$ \\ Received: 11/12/2010 Accepted: 26/02/2011
}

\begin{abstract}
${ }^{1}$ Dpto. de Sociología I. Apartado de Correos. 99. Universidad de Alicante. E-03080 Alicante, Spain; tel: +34 965903400; fax: +34 965909552; email: alejandro.mantecon@ua.es

${ }^{2}$ Dpto. de Sociología I. Apartado de Correos. 99. Universidad de Alicante. E-03080 Alicante, Spain; email: r.huete@ua.es

* Corresponding author
\end{abstract}

\section{Abstract}

This paper analyses the attitudes of residents in a region of the Spanish Mediterranean coast where tourism is mainly based on the building of second homes, often on a massive scale. A face-to-face survey $(n=430)$ conducted within the Spanish population indicates that the ideological context in which residential tourism has developed with such intensity is contained in a framework of social legitimisation. However, it is possible to distinguish between two groups: the defenders, who tend to view the region as one that is essentially tourist in nature, and the critics, who place greater emphasis on the property dimension. The former tend to justify this process and its evolution by recognising the economic benefits it may bring, whereas the latter tend to question the socio-cultural and environmental costs of such development.

(C) 2011 International University College. All rights reserved

Keywords: resident attitudes, second homes, legitimisation, Spain.

Citation: Mantecón, A., R. Huete (2011) Sociological insights on residential tourism: host society attitudes in a mature destination. European Journal of Tourism Research 4(2), pp. 109-122

\section{Introduction}

Between the late 1950s and the early 1960s, in the midst of Franco's dictatorship, Spain began its modernisation, which was mainly based on a fusion between tourism activity and real estate industry. Over the last five decades, residential tourism has brought about a sustained increase of property supply, and has drawn many people to the country; a warm climate with beneficial effects on health, affordable prices, and a 'friendly atmosphere' (a blend of natural and social environments) appeal to some of them, whereas others are attracted by work opportunities associated with the real estate industry. As is the case with many other processes in advanced capitalism, we can nowadays observe how the dynamics of residential tourism have come up against the environment's carrying capacity. However, this fact has not given rise to a clear rejection of the relationship between tourism and real estate business on the part of the local population.

We have studied, through a quantitative research approach, the attitudes toward residential tourism of residents of the towns 
where this tourism development model has grown more intensely. This paper puts forward a sociological explanation of how the host society has legitimised mass tourism based on the construction of second homes, a tourism model distinctive of the Mediterranean coast in southern Spain. In recent years, parts of the world unconnected to this type of tourism have opted for similar models of tourism development, such as Brazil (Assis, 2006), Mexico (Hiernaux, 2005), India (Nigam \& Kumar, 2009) and South Africa (Visser, 2004). Thus, a study of a mature destination as the Spanish case may be of interest to other places involved in the initial stages of the residential tourism process.

\section{Literature review}

The authorities responsible for managing tourism in the Spanish Mediterranean have recently become aware of an indisputable reality that now exists elsewhere: there can be no successful planning for tourism development without first knowing and taking into account the attitudes of the local population. It is assumed, therefore, that when residents of tourist resorts have attitudes that oppose the interests of planners, such planners run the risk of not achieving their objectives (Allen et al., 1988; Ap, 1992; Harrill, 2004; Ritchie \& Inkari, 2006). For 30 years, this axiom has led to studies on the host society's perception of the impact of tourism. Such studies tend to focus on the perception of the economic (Gilbert \& Clark, 1997; Haralambopoulous \& Pizam, 1996; Johnson et al., 1994; Liu \& Var, 1986; Perdue et al., 1990; Smith \& Krannich, 1998; Tosun, 2002), sociocultural (Brunt \& Courtney, 1999; Pizam, 1978) and environmental effects (Bujosa \& Rosselló, 2007; Vera \& Ivars, 2003).

One of the most successful frames explaining the host society attitudes is the Social Exchange Theory whose main idea states that residents will support tourism development as long as they perceive that any potential benefits will be greater than the costs (Ap, 1992; Gursoy et al., 2002). From its perspective, it can be observed that people employed in the tourist industry express more positive opinions about tourism than those of people who are not employed (Pizam, 1978). Most researchers have confirmed this principle (Andereck et al., 2005; Jurowski et al., 1997; King et al., 1991; Perdue et al., 1990), although it has also been suggested that data interpretation needs to be enriched by using perspectives other than the predominant focus of the social exchange theory, since contradictory results have sometimes been observed (Andereck et al, 2005). Specifically, Smith \& Krannich (1998) note that residents of communities, that are economically dependent on tourism, perceive its impact more negatively than inhabitants of less dependent communities. Furthermore, Teye, Sönmez \& Sirakaya (2002) put forward that people who work in businesses relating to tourism have a negative attitude toward the sector.

No consensus can be said to exist on the factors that determine how host societies perceive tourism. For example, in studies analysing the influence of the interaction between tourists and residents, some researchers explain that smaller distances between residents' homes and the places frequented by tourists lead to more positive attitudes, as the population of such places tends to be more financially dependent on tourism (Belisle \& Hoy, 1980). However, other studies would seem to demonstrate the exact opposite, arguing that negative attitudes are the result of greater proximity (Mansfeld, 1992). According to these experts, residents see tourists as competing in the consumption of scarce resources, and feel that the affluence of tourists causes problems relating to daily inconveniences, such as noise and traffic congestion (Jurowski \& Gursoy, 2004).

Another factor studied in depth is the residents' length of stay in the locality. Some authors conclude that the longer a person has lived in a tourist resort, the more critical their attitude to tourism becomes and, logically, the less time they have spent, the more favourable their attitude (Brunt \& Courney, 1999; Cavus \& Tanrisevdi, 2002; Ryan \& Montgomery, 1994). However, other studies posit that residents who have only recently arrived are more critical (Brougham \& Butler, 1981), perhaps because they fear that tourism may endanger the peace 
and quiet that they seek when moving home (Faulkner \& Tideswell, 1997).

Furthermore, researchers who have analysed the usual socio-demographic and socioeconomic variables (gender, age, income, profession, levels of study, and rural or urban environment) have also been unable to reach any conclusive results (Liu \& Var, 1986), or the findings are contradictory between studies (Huh \& Vogt, 2008).

Those who have attempted to unravel this issue by focusing on which stage of development the resort is in have also failed to reach any definitive agreement. Although it may at first seem logical to explain that moderate tourism development is usually perceived positively and that, equally, as this development intensifies, so do the more negative opinions, it turns out that this argument has also been placed in doubt (Diedrich \& García-Buades, 2009; Faulkner \& Tideswall, 1997).

The complexity of the situation of tourism, and the almost infinite variety of contexts in which it exists, has meant that no explanations have been put forward with any universal validity. This study presents an explanation in a mature residential tourist context, where the usual socioeconomic and socio-demographic variables fail to provide explanations.

\section{The Spanish context}

Spain is undoubtedly one of the countries that have shown the most change since the beginnings of mass tourism in the 1960s. Researchers have spent four decades analysing the causes and consequences of these changes, paying particular attention to aspects such as economy (Gaviria, 1976; Jurdao, 1979; Monfort \& Ivars, 2001; Vera \& Marchena, 1996), environment (González et al., 2006; Huete, 2005), town planning (Barke, 1991; Mazón, 1987, 2006; Pedro, 2006) and socio-demography (Casado, 2006; O'Reilly, 2003; Salvà, 2002). Fieldwork has usually been carried out in the Mediterranean coastal regions (and the Canary Islands), as the process has been most marked in these areas. However, it has not been until more recent times that researchers into the tourism process in Spain have turned their attention to the attitudes of the host society (Aguiló \& Rosselló, 2005; Bujosa \& Rosselló, 2007; Huete et al., 2008; Mantecón, 2010; Mantecón \& Huete, 2008).

It may be paradoxical that a country such as Spain, which has been so pioneering in its development of the tourist industry and where mass tourism has evolved with such intensity, has also taken so long to research the view of the host society. The reasons for such a delay are well known: from the very beginning of mass tourism on the Spanish Mediterranean coast, the authorities denied society the responsibility (and the right) of stating its opinion on how tourism should develop. Instead, the political elite took a monopolistic attitude to all its assessments, in this case by proclaiming a legitimising discourse that was hegemonic in nature for decades. This discourse had its roots in the political rhetoric of the Franco dictatorship of the 1960s. Its purpose was one of publicity, with two main objectives: to project a "friendly" image of Spain to the countries from where tourists originate, on the one hand, and to convince Spaniards of the indisputable need to increase the number of foreign tourists each year. Any criticism was seen as opposing the only possible way for the country to modernise. The reason behind this insistence was to provide a measure of equilibrium to a precarious economic system that was held up by the funds sent back to the country by the thousands of Spanish migrants that provided manual labour for factories in France, Switzerland and Germany. The two objectives mentioned above reflect the "ideological and economic instrumentalisation" of tourism by the Francoist authorities; an instrumentalisation that fitted perfectly within the context of the ideology of development that dominated Spanish politics in the 1960s and early 1970s. This has influenced our conception of tourism to the present day, by voiding (and silencing) until recent years any critical or alternative opinions (Mantecón, 2010). Such discourse is in line with a policy aimed at securing immediate economic benefits by increasing tourist numbers, rather than planning for sustainable development and 
adjusting demand to the specific characteristics of each region (Vera \& Ivars, 2003).

If it is possible to identify such an "ideological instrumentalisation" of tourism during the Franco years, a "property instrumentalisation" within tourism can also be identified during Spain's democratic era (1978-today) (Vera \& Marchena, 1996). This translates into a political discourse from the local councils of tourist resorts, one that consists of identifying the construction industry (and the economic activities directly associated with it) with the tourist sector, leading to a model of tourism based not on tourist developers, but on property developers, who are principally guided by speculative interests (Mazón, 2006).

Most of the Spanish Mediterranean coastal towns have undergone their own particular process of modernisation, based on what is known as residential tourism: an activity associated not only with the traditional forms of summer vacation, but also with the emergence of new lifestyles and types of residential mobility associated with the widespread construction of second homes (Huete et al., 2008). Researchers are divided on how best to define and approach this phenomenon (Mazón, 2006; Monreal, 2001, Raya, 2001; Salvà, 2002). In the Mediterranean societies, the conceptual problem is closely linked to the highly complex dynamics of intra-European migrations (Gustafson, 2008; King, 2002; O'Reilly, 2003; Williams et al., 2000). This involves deciding whether people who live for relatively long periods of time in homes in tourist areas (due to reasons that have more to do with the search for a place in which to enjoy their leisure time rather than undertaking any economic activity), should be considered residents or tourists (Huete, 2009; Huete \& Mantecón, 2010).

Beyond the conceptual problems, the residential tourism process has become a hegemonic development strategy in almost all tourist resorts along the Spanish coastline with few exceptions like Benidorm. Today the region is sustained by the economic activity generated by the construction, sale, rent and fitting out of second homes.
For this study, the coastal region in the south of Alicante province was chosen, comprising the towns of Santa Pola, Guardamar and Torrevieja. This area is a typical case for the coastal region, with a residential dynamic bordering on saturation, with an appreciable overcrowding of tourism-linked property construction.

The region's socioeconomic situation is better understood upon observing that there are more businesses and employees directly linked to the construction industry and property development than to the hospitality sector. According to the Social Security General Treasury, in 2008 there were 1,216 businesses linked to the construction and property development sector $(26.7 \%$ of the total), with 5,593 employees (26.2\% of the total), compared with 779 businesses $(17.1 \%$ of the total) linked to the hospitality sector, giving work to 3,244 employees $(15.2 \%$ of the total).

The relationship between the total number of homes and the subset of second and empty homes indicates the real importance of the property sector in this area. According to data released by the National Institute of Statistics, the 119,303 homes for potential tourist use make up $78.6 \%$ of the total number of properties $(151,814)$, confirming the dominant presence of residential tourism. Whilst at the height of summer the region can receive more than 800,000 visitors, its 27 hotels can only accommodate 4,081 tourists according to the Valencian Institute of Statistics (2008).

This study considers the following hypothesis: the critical appraisal by researchers of the evolution of tourism and the property process in the Spanish Mediterranean regions (Aledo \& Mazón, 2004; Gaviria, 1974, 1975, 1976; Jurdao, 1979; Mazón, 1987, 2006; Monfort \& Ivars, 2001; Vera, 1987, 1990, 1995, 2005; Vera \& Marchena, 1996), does not correspond to the positive perception of the process given by the majority of citizens.

To this end, this study analyses the attitudes of residents toward tourism in a region on the Spanish Mediterranean coast in the south of the province of Alicante, where the typically 
Spanish development model based on the building of second homes on a massive scale, is most clearly manifest. The analysis of the perceptions of tourism development will also provide insight into new forms of interpretation, since the variables studied up to now fail to clarify the key sociological factors that determine the host population's opinion of tourism development.

\section{Methodology}

The data were collected through a face-to-face survey with residents in the area aged 18 years or over who had been included in the 2001 census. From a population of 71,475 inhabitants, 430 people were surveyed (97 in Guardamar del Segura, 152 in Santa Pola and 181 in Torrevieja). A stratified sampling method based on proportional allocation was used. This sample is statistically representative of the area population, with a margin of error of \pm $4.71 \%$, a $2 \Omega(95 \%)$ level of confidence, and a population variance of $50 \%$. A structured questionnaire directed by interviewers was administered to this sample in April and May 2008. The survey featured 44 statements or questions, grouped by subject into five sections: a) opinion on the town's economic situation; b) the relation between tourism and economic development; c) appraisal of the different cultural and environmental effects; d) opinion about tourists; and e) sociodemographic and statistical classification questions. To strengthen internal reliability, the questionnaire was pretested on a convenience sample of 30 local residents. All statistics were computed using SPSS $16^{\odot}$ software.

\section{Results}

The results reveal that there is broad consensus in the positive assessment given of the impact of tourism on the towns where the respondents live. Four response options were considered to define participants' opinions on tourism: $15.2 \%$ of the population feel that tourism is the only possible way for the town to develop; $39.7 \%$ think that tourism is the best way, though there are others; $40.8 \%$ state that tourism could be a way for the town to develop, though other activities should be strengthened; and $4.3 \%$ say that business alternatives need to be developed, because tourism is finished.
Thus, by adding together the first three items, $95.7 \%$ consider tourism as a way to ensure local development. The minority that believes that tourism is finished does not fit any sociodemographic profile. Analysis of variance and the chi-square test have shown that in this group there are both old and younger people, born in the town and elsewhere, with differing levels of study, differing incomes, differing votes in the last elections, and so on. Similarly, no significant relationships were found between those who do and do not work in the tourist sector.

The population's trust in tourism to ensure local economic development is backed up by their response to the question "Are you in favour of tourism in your town?", only $2.5 \%$ give no for an answer. When considering possible alternatives to tourism for economic development, only $9.5 \%$ of the population agrees with the notion of "rejecting tourism and basing the economy on other sectors to improve the town's future".

The population can be divided into those who feel that tourism is the only or best means of development, and those who in some way question this supposition. Following statistical confirmation of the validity and consistency of this grouping, two profiles can be established: the group of "defenders" of tourism (comprising $54.9 \%$ of respondents, including those who feel that tourism is the only way forward for economic development, and those who feel it is the best way forward) and the "critics" (the remaining $45.1 \%$, made up of individuals who think that "other activities need to be strengthened" and the small group of interviewees who think that tourism is "finished").

According to previous research, it would be expected for these two groups to fit a certain socio-demographic pattern. However, statistical tests based on variance analysis (ANOVA) and chi-square test show that there is no statistical relationship in the positioning of either of the two groups using the variables relevant in other studies. Thus, there is no significant difference in opinion when taking income level into account $(F=1.99, \rho=0.158)$, the interviewees' 
Table 1. Descriptive summary of participants

\begin{tabular}{|c|c|c|}
\hline Socio-demographic Variable & $\mathbf{N}$ & $\%$ \\
\hline \multicolumn{3}{|l|}{ Gender $(\mathrm{N}=430)$} \\
\hline Male & 218 & 50.7 \\
\hline Female & 212 & 49.3 \\
\hline \multicolumn{3}{|l|}{ Age $(\mathrm{N}=430)$} \\
\hline $18-44$ & 229 & 53.2 \\
\hline$>=45$ & 201 & 46.8 \\
\hline \multicolumn{3}{|l|}{ Income per month ( $\mathrm{N}=366)$} \\
\hline Under $999 €$ & 58 & 15.8 \\
\hline $1.000-1.999 €$ & 167 & 45.6 \\
\hline $1.999-2.999 €$ & 132 & 36.1 \\
\hline 3.000 or more & 9 & 2.5 \\
\hline \multicolumn{3}{|l|}{ Education $(\mathrm{N}=429)$} \\
\hline Sixth grade or less & 38 & 8.9 \\
\hline Less than 12th year & 65 & 15.2 \\
\hline Some college & 215 & 50.2 \\
\hline High school graduate & 75 & 17.5 \\
\hline University graduate & 36 & 8.4 \\
\hline \multicolumn{3}{|l|}{ Employment $(\mathrm{N}=430)$} \\
\hline Employed & 237 & 55.1 \\
\hline Retired & 82 & 19.1 \\
\hline Student & 10 & 2.3 \\
\hline Not currently employed & 38 & 8.9 \\
\hline Full-time homemaker & 63 & 14.7 \\
\hline \multicolumn{3}{|c|}{ Is your employment related to tourism? $(\mathrm{N}=348)$} \\
\hline Nothing & 118 & 27.4 \\
\hline Little & 55 & 12.8 \\
\hline Quite a lot & 113 & 26.3 \\
\hline A lot & 62 & 14.4 \\
\hline
\end{tabular}

working relationship with the tourist sector $\left(x^{2}=1.117\right.$, d.f., $\left.3, \rho=0.773\right)$, or the number of people that work in the sector at home $(F=0.001, \rho=0.973)$. There is no significant difference when taking into account the years living in the area $(F=0.009, \rho=0.925)$ or age $(F=0.191, \quad \rho=0.663)$, and no significant differences are found when considering the level of study $\left(X^{2}=10.508\right.$, d.f. $\left.8, \rho=0.231\right)$, the vote in the last election $(F=0.041, \rho=0.840)$, or the place of residence (town centre or outskirts) $\left(X^{2}=0.393\right.$, d.f. $\left.2, \rho=0.821\right)$.

With regard to whether respondents are "in favour of there being tourism in their town", however, there is a significant difference between the groups (table 2). Those whose answer depends on the "type of tourism" are mostly in the group of "critics", whereas those who give a directly favourable answer are mostly in the group of "defenders".

It is important to emphasise that the differences between "defenders" and "critics" are within a general context of legitimisation. Another fact supporting this thesis is that $79.4 \%$ of the "defenders" think that their town should continue to grow in line with the current development, compared with $69.9 \%$ of the "critics" ( $X^{2}=4.837$, d.f. $\left.1 ; \rho=0.028\right)$.

\subsection{Effects on the economy}

This section analyses the two groups' opinions on the economic impact of tourism. 
Table 2. Are you in favour of tourism in your town? According to the profiles of "defenders" and "critics"

\begin{tabular}{lrcc}
\hline & \multicolumn{3}{c}{ Opinion (\%) } \\
\cline { 2 - 4 } & Defenders & Critics & Total \\
\hline Yes & 96.7 & 85.8 & 91.4 \\
No & 0.9 & 4.2 & 2.4 \\
Depends on the type of tourism & 3.0 & 10.0 & 6.2 \\
Total & 100 & 100 & 100 \\
\hline$X^{2}=14.323, d f .2 ; \rho=0.001$ & &
\end{tabular}

$X^{2}=14.323$, d.f. $2 ; \rho=0.001$

Table 3. Perception of the most important economic activity according to the profiles of "defenders" and "critics"

\begin{tabular}{lrrc}
\hline & \multicolumn{3}{c}{ Opinion (\%) } \\
\cline { 2 - 4 } & Defenders & Critics & Total \\
\hline Construction & 18.6 & 57.6 & 24.3 \\
Commerce & 3.5 & 69.2 & 6.4 \\
Agriculture and fishing & 6.6 & 40.0 & 6.1 \\
Tourism & 69.5 & 37.9 & 62.0 \\
Industry & 1.8 & 20.0 & 1.2 \\
Total & 100 & 100 & 100 \\
\hline
\end{tabular}

$X^{2}=19.103$, d.f. $4, \rho=0.001$

Table 3 shows that, considered as a whole, the population thinks that tourism is the main economic activity in their town, followed by construction. However, there are differences in the groups: whereas $69.5 \%$ of the defenders think that tourism is the town's main activity, only $37.9 \%$ of the critics share this view. On the other hand, construction is perceived as the main activity by $57.6 \%$ of the critics, compared with $18.6 \%$ of the defenders.

Asked about the influence of tourism on other economic activities, both groups think that tourism has a decisive influence over construction, but the defenders express this opinion to a greater degree than the critics do: $67.2 \%$ of the "defenders" (compared with $50.3 \%$ of the "critics") think that there is "much" influence, whereas $31.5 \%$ of the "defenders" (compared with $44 \%$ of the "critics") think that there is "quite a lot" of influence $\left(X^{2}=16.021\right.$ d.f. $3, \rho=0.001)$. That is, when asked about the main economic activity, those more in favour of tourism think that it is the main economic activity, but also think that it has a major influence on the construction industry.

Interviewees were also asked about the ability of tourism to create jobs in their town. A total of $83 \%$ think that there is more work thanks to tourism, though they feel that it is not highquality employment (73\%). In an analysis of the results according to the two profiles of "defenders" and "critics", it is clear that the critics have less trust in this contribution of tourism to the economy (figure 1)

It could be thought that one of the key factors in assessing tourism is the perception of which local social agents or collectives most benefit from tourism. Indeed, there are significant differences between the two profiles. Even though "defenders" and "critics" alike think that construction companies and property developers most benefit from tourism, there are some differences when assessing the benefit obtained by other social agents. Thus, $8.1 \%$ of the defenders think that other business sectors also benefit, an opinion shared by only $3.4 \%$ of 


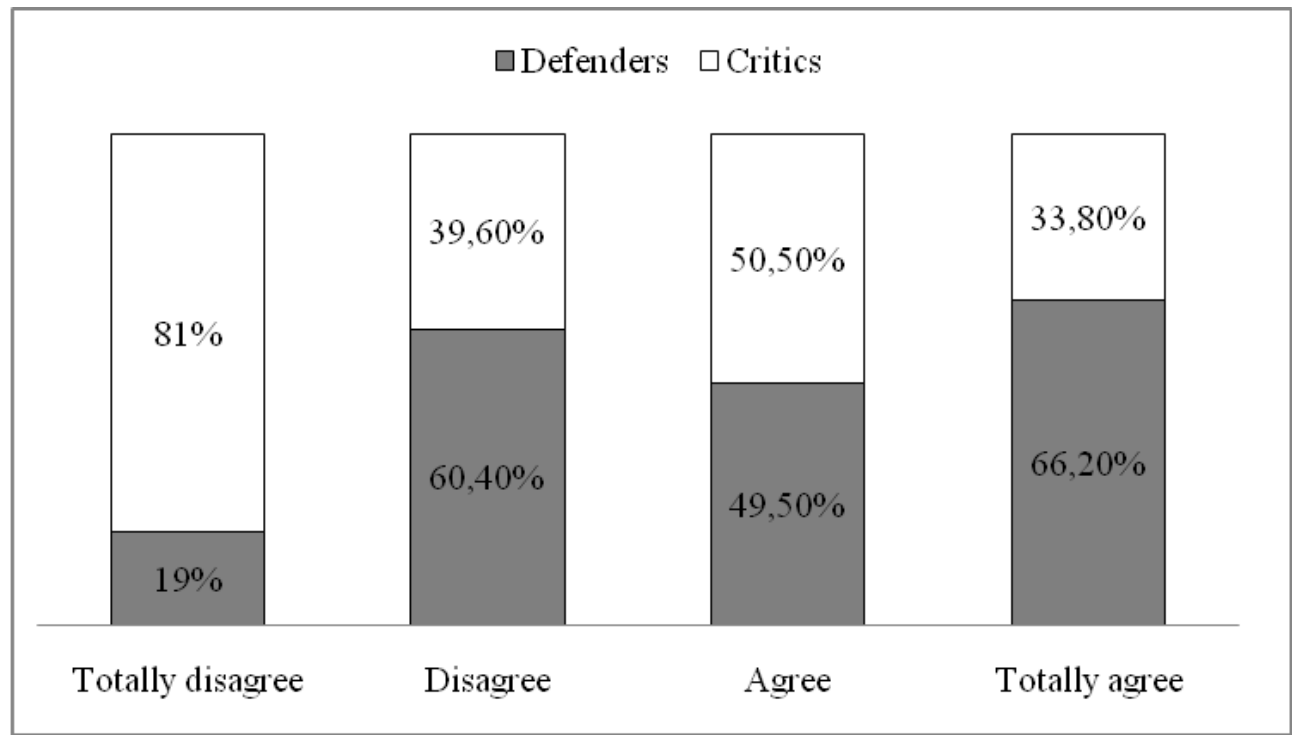

$X^{2}=21.824$, d.f. $3 ; \rho=0.000$

Figure 1. Degree of agreement with the statement "There is more work in the town thanks to tourism" according to the profiles of "defenders" and "critics"

the critics; $31.5 \%$ of the defenders think that the commerce sector benefits from tourism, compared with $10.7 \%$ of the critics. However, $15.2 \%$ of the critics think that politicians obtain major economic benefit from tourism, compared with $9 \%$ of the defenders $\left(X^{2}=35,087\right.$, d.f. $\left.5, \rho<0.000\right)$.

\subsection{Socio-cultural repercussions}

To measure the perception of the socio-cultural change linked to tourism, a seven-item semantic differential scale was used. In this question, participants were asked to score various adjectives with the aim of gathering their opinion on possible trends caused by tourism that best describe their towns. Again, certain significant differences are found when analysing the results in terms of the distinction between "defenders" and "critics":

Traditional/Modern. The "defenders" are more homogenous in their response to this question, giving scores mainly from 4 to 7 (more or less traditional or moderately modern), whereas the "critics" were more erratic in their opinions (a broader spread of answers), with a higher number of scores from 6 to 8 . In other words, a greater number of "critics" than of "defenders" think that the adjective "modern" (rather than "traditional") can be applied to describe the current situation of their town. This is also true when comparing box-plot graphs (figure 2), which show a greater range of variation for the "critics", and a higher median score.

Busy/Quiet. In this case, opinion is clearly divided (bimodality) for both "defenders" and "critics", as well as for the population in general, but the "defenders" give scores of mostly 7 to 9 , closer to "quiet", whereas the "critics" have more scores from 1 to 4 , closer to "busy".

Boring/Lively. As with the previous case, opinions are divided. The "defenders" tend to give lower scores (closer to "boring"), whereas the "critics" often feel that it is "lively".

Unsafe/Safe. The previous trend is repeated, but with a high number of "critics" giving very low scores, close to the "unsafe" end of the scale. The "defenders" are clearly divided, although a high number give "safe" scores. The difference between the two profiles is most significant here: the perception of "unsafe" is much higher among the critics. 

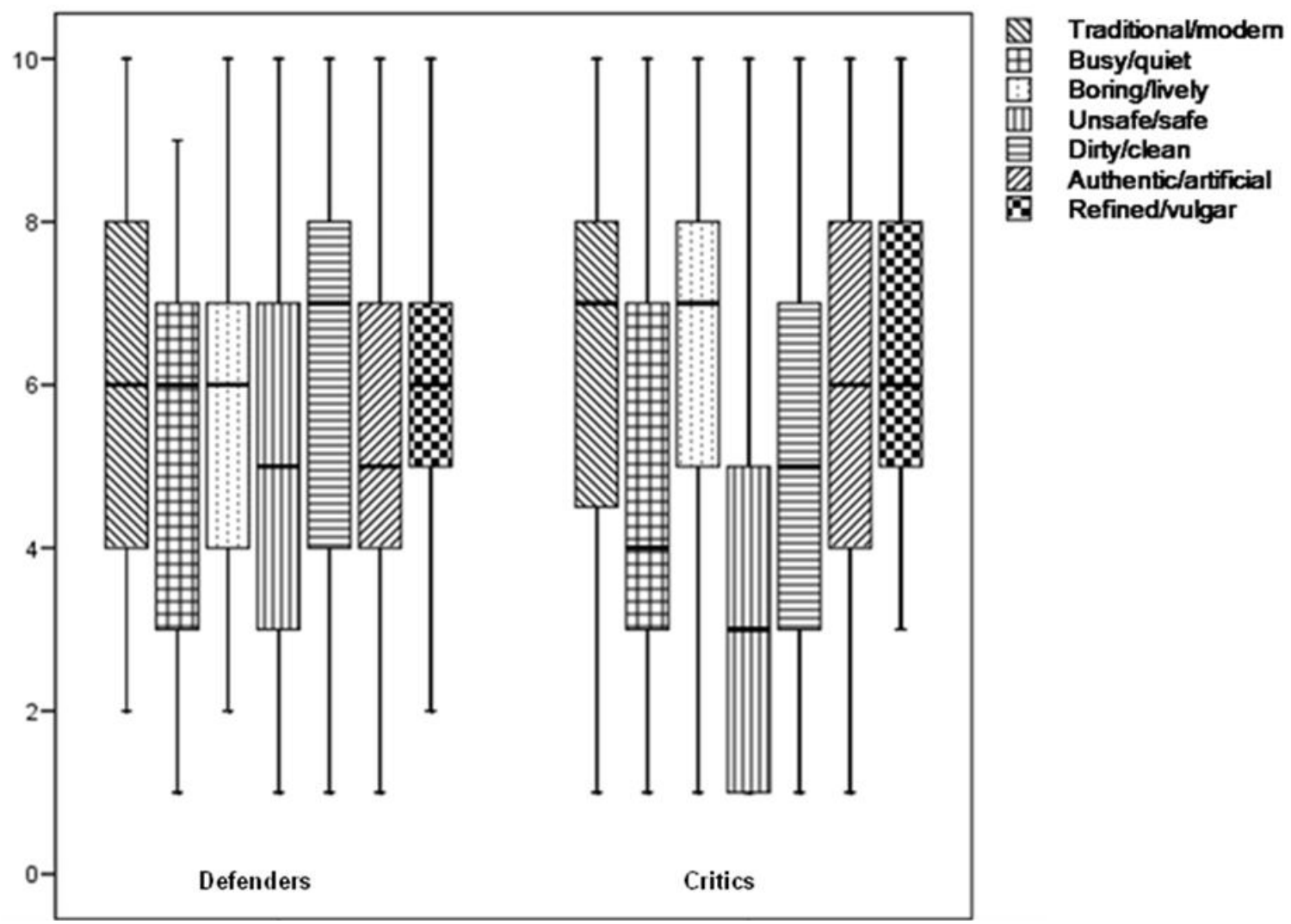

Figure 2. Characteristics of the town associated with tourism development according to the profiles of "defenders" and "critics"

Dirty/Clean. In this case, there is a broad spread of opinion among the two profiles, but there is a more notable tendency for the "defenders" to give "clean" scores than the "critics".

Authentic/Artificial. Again, opinion is quite divided, with a greater concentration of scores from 8 to 10 ("artificial") among the critics.

Refined/Vulgar. There is a tendency for the participants to consider their town moderately vulgar (with a higher concentration of scores from 5 to 7), with the "critics" giving the highest scores ("vulgar").

It should be noted that the broad spread observed in most boxes is due to the bimodality tendency of several of the characteristics analysed, as stated. This indicates the division of opinions with regard to the variables analysed. As figure 2 shows, the "critics" are most likely to think of their town as modern, busy, lively, unsafe, dirty, artificial and vulgar. The "defenders", on the other hand, tend to think of their town as traditional, quiet, boring, safe, clean, authentic and somewhat more refined.

With regard to interaction between tourists and residents, three questions clarify the differing perception of the two profiles. More of the "defenders" than the "critics" think that tourists do take part in their town's festivities $(81.3 \%$ against $70.1 \%, X^{2}=6.981$, d.f. $\left.1 ; \rho=0,008\right)$, and more of them think that this is a good thing $\left(68.2 \%\right.$ against $43.5 \% ; \quad X^{2}=25,943$, d.f. 2; $\rho<0.000)$. In this same sense, $59.9 \%$ of the "critics" think that the tourists that visit their town are not interested in the local culture, an opinion that is only shared by $40.1 \%$ of the defenders $\left(x^{2}=7.814\right.$, d.f. $\left.1, \rho<0.005\right)$. The 
Table 4. Perception of whether not tourists that come respect the environment, according to the profiles of "defenders" and "critics"

\begin{tabular}{lrrr}
\hline & \multicolumn{3}{c}{ Opinion (\%) } \\
\cline { 2 - 4 } & Defenders & Critics & \multicolumn{1}{c}{ Total } \\
\hline Yes & 65.1 & 50.6 & 58.3 \\
No & 34.9 & 49.4 & 41.7 \\
Total & 100 & 100 & 100 \\
\hline
\end{tabular}

$X^{2}=7.814$, d.f. $1 ; \rho=0.005$

Table 5. Degree of agreement: I am worried about the impact of tourism on the environment, according to the profiles of "defenders" and "critics"

\begin{tabular}{lccc}
\hline & \multicolumn{3}{c}{ Opinion (\%) } \\
\cline { 2 - 4 } & Defenders & Critics & Total \\
\hline Totally agree & 11.7 & 17.1 & 14.1 \\
Agree & 24.7 & 30.4 & 27.2 \\
Disagree & 19.9 & 28.7 & 23.8 \\
Totally disagree & 43.7 & 23.8 & 35.0 \\
Total & 100 & 100 & 100 \\
\hline
\end{tabular}

$X^{2}=18.241$, d.f. $3 ; \rho<0,000$

majority of those surveyed think that tourists do interact with the local population, although more of the "defenders" feel this statement to be true $(71.7 \%$ against $54.3 \%$ agree that "the tourists who come interact with the local population" $X^{2}=13.507$, d.f. $\left.1 ; \rho<0.000\right)$.

\subsection{Impact on the environment}

An appraisal of the environmental impact of tourism is explored here in terms of the perception of tourists and the concern shown with regard to the impact that tourism has on the environment. The first issue is analysed according to the degree to which residents agree or disagree with the statement that "the tourists that come respect the environment". The results back up the existence of a dichotomous discourse within a general context of legitimisation. The group of "defenders" state that tourists are respectful of the environment to a greater degree than the "critics" do, but once again it is observed that this happens in a context of ideological legitimisation, as shown by the fact that $58.3 \%$ of those interviewed agree with the statement. However, $59.2 \%$ of the 211 respondents that do agree are "defenders". Only $40.8 \%$ of the "critics" agree that the tourists that visit the town respect the environment. At the same time, of the $41.7 \%$ of those that disagree, only $34.9 \%$ are "defenders", whereas the percentage reaches 49.4\% among the "critics".

The "critics" tend to be more concerned than the "defenders" by the impact of tourism on the environment, as can be observed in table 5 .

\section{Discussion}

The studies undertaken by most experts researching the effects of how mass tourism has evolved on the Spanish Mediterranean coastline have produced fairly critical diagnoses. What these studies tend to have in common is a criticism of the negative effects of overcrowding and the substitution of planned tourism for uncontrolled urban development linked to speculative property processes. However, the results presented in this study indicate that the ideological context in which residential tourism has developed so intensively in these regions is within a context of social legitimisation, proof of which is that only $4.3 \%$ of those surveyed think that "tourism is finished and economic and business alternatives need to be found". 
It was not possible to prove the influence of the factors most commonly studied by the specialised literature in an attempt to comprehend the situation. Variables such as age, level of studies, vote in the last election, how long they have lived in the town and their place of residence (town centre/outskirts) have shown no significant differences. Applying the social exchange theory to interpret the data is also difficult, as the relationship between the interviewees' level of income and their view of tourism gives no conclusive results. The explanation may be related to cost and benefit analyses from collective viewpoints. In other words, the population's support for tourism could be better understood as a desire for increased wealth and employment for the town (for the collective) rather than as personal economic interest (similar to the explanation given by Vargas et al., 2009). In any case, personal benefit can be perceived as an indirect desire by applying the following logic: if the town's wealth increases from tourism, it is likely that $\mathrm{I}$, a resident in the town, regardless of what my job is, will end up benefiting in some way. This reasoning is most noticeable among the "critics", who to a greater degree than the "defenders", think that all citizens benefit from the progress. In this sense, the "defenders" seem to place greater emphasis on economic growth (with a greater perception of the concentration of economic benefits in the sectors of "commerce" and "other entrepreneurs"), whereas the critics tend to think in terms of social benefits, i.e. distribution of wealth among all citizens: $57.9 \%$ of those who think that all citizens benefit are "critics". By placing this interpretation within the context of the predominant discourses on tourism in Spain since its origins in the 1960s, the explanation makes sense.

Nevertheless, the analysis carried out shows that behind this argument there is a more complicated reality. Within the context of general legitimisation, it is possible to distinguish between two large groups. The first, here called the "defenders", is made up of those people who show stronger support for development. This includes the $15.2 \%$ who think that tourism is the only way to guarantee progress, and the $39.7 \%$ who, although admitting that there are other ways, feel that tourism is the best way for their town. The second group, the "critics", includes the $40.8 \%$ who, while accepting the legitimacy and value of tourism for local development, think that the time has come to complement tourism with other better activities, and the $4.3 \%$ who think that tourism is finished. Thus the criterion that differentiates the two groups is the presence of a more or less intense questioning of the current residential tourist situation, although this questioning does not necessary imply a delegitimisation of the situation.

This classification has made it possible to present a series of statistically significant differences that characterise the two groups. The "defenders" show decided support of the tourist patterns in their towns. This support is linked to their belief in tourism as the town's most important economic activity and the engine driving the construction industry. In this regard, this group has greater trust in the ability of the tourist industry to create jobs, and recognises its power in boosting other economic sectors besides property development. At the same time, this group thinks that the socio-cultural effects of tourism have not been as intense as the "critics" do. The "defenders" think that their town is close to a "pure type": traditional, quiet, boring, safe, clean, authentic and refined. They are also more benevolent in their appraisal of the relationship between tourists and the environment.

The "critics" make their support dependant on the restructuring of the established residential tourist model, although, in a lesser degree than the "defenders", they clearly agree that their town should continue to grow. This questioning of the current tourist situation is related to a perception of lesser economic dependence on the tourist industry, since, for this group, the real economic engine would be construction, with tourism relegated to a secondary plane. In this regard, the "critics" also perceive a lesser influence of tourism on the building trade and, in general, are more sceptical when appraising its ability to create jobs and to boost other economic sectors. In terms of socio-cultural aspects, the members of this group see their town as more of a modern, busy, lively, unsafe, 
dirty, artificial and vulgar place. The "critics" also tend to condemn the tourists' relationship with the environment.

\section{Conclusions}

This study has analysed the attitudes of the host society with regard to tourism in the context of mature mass tourism, the main characteristic of which is the almost hegemonic presence of residential tourism. Even though for years experts have warned of an impending crisis in the system and criticised development processes as economically, cultural and environmentally irrational, such considerations have failed to take into account that the resident population's perception of tourism in no way calls for a delegitimisation of the logic behind the usual forms of action. Nevertheless, this study has determined that beneath the surface of legitimisation, there is a secondary ideological layer with a dichotomous structure that helps to understand the real value that the host society feels that tourism has. Data analysis indicates that the discourse concerning tourism can be explained in terms of its own configuration, i.e. that "defenders" and "critics" witness the same reality but interpret it differently. The defenders tend to view the region as one that is essentially tourist in nature, and justify how the tourist process has evolved by pointing out the economic benefits that it brings, whereas the "critics" place greater emphasis on the property dimension, and tend to question to a greater degree the socio-cultural and environmental costs of development. This explains the dichotomous nature of public opinion, but does not respond to the usual socioeconomic and socio-demographic independent variables.

\section{Acknowledgement}

The authors acknowledge the financial support from the Ministerio de Ciencia e Innovación to the project: "The social perception of tourism in the Valencian Region. A sociological and prospective analysis (CSO2009-10293)" directed by $\mathrm{Dr}$ Tomás Mazón, Institute for Tourism Research, University of Alicante. We are grateful to him and to Dr Elena Jorge for their support.

\section{References}

Aguiló, E., \& Rosselló, J. (2005). Host community perceptions. A cluster analysis. Annals of Tourism Research 32(4), 925-941.

Aledo, A., \& Mazón, T. (2004). Impact of Residential Tourism and the Destination Life Cycle Theory. In Pineda, F.D. \& Brebbia C.A. (eds.) Sustainable Tourism. Southampton, Boston: WIT Press, pp. 25-36.

Allen, L., Long, P., Perdue, R., \& Kieselbach, S. (1988). The impact of tourism development on residents' perceptions of community life. Journal of Travel Research, 27(1), 16-21.

Andereck, K. L., Valentine, K. M., Knopf, R. C., \& Vogt, C. A. (2005) Residents' perceptions of community tourism impacts. Annals of Tourism Research 32(4), 1056-1076.

Ap, J. (1992). Residents' Perceptions on Tourism Impacts. Annals of Tourism Research 19(4), 665-690.

Assis, L. F. (2006). Residências secundárias: expansão e novos usos no litoral cearense. In da Silva, J.B., Dantas, E.W.C., Zanella, M.E., \& Meireles, A.J. de A. (eds.) Litoral e sertão: natureza e sociedade no nordeste brasileiro. Fortaleza: Expressão Gráfica, pp. 289-305.

Barke, M. (1991). The growth and changing pattern of second homes in Spain in the 1970s'. Scottish Geographical Magazine 107(1), 12-21.

Belisle, F., \& Hoy, D. (1980). The Perceived Impact of Tourism by Residents. Annals of Tourism Research 7(1), 83-101.

Brougham, J., \& Butler, R. (1981). A Segmentation Analysis of Resident Attitudes to the Social Impacts of Tourism. Annals of Tourism Research 8(4), 569-590.

Brunt, P., \&. Courtney, P. (1999). Host Perceptions of Sociocultural Impacts. Annals of Tourism Research 26(3), 493-515.

Bujosa, A., \& Rosselló, J. (2007) Modelling environmental attitudes toward tourism. Tourism Management 28(3), 688-695.

Casado, M.A. (2006) Retiring to Spain: An Analysis of Differences among North European Nationals. Journal of Ethnic and Migration Studies 32(8), 1321-1339.

Cavus, S., \& Tanrisevdi, A. (2002). Residents' Attitudes toward Tourism Development: A Case Study in Kusadasi, Turkey. Tourism Analysis 7(3/4), 259-269.

Diedrich, A., \& García-Buades, E. (2009). Local perceptions of tourism as indicators of destination decline. Tourism Management 30(4), 512-521.

Faulkner, B., \& Tideswell, C. (1997). A framework for monitoring community impacts of tourism. Journal of Sustainable Tourism 5(1), 3-28. 
Gaviria, M. (1974). La producción neocolonialista del espacio. Papers. Revista de Sociología 3, 201-217.

Gaviria, M. (1975) El turismo de playa en España. Madrid: Turner.

Gaviria, M. (1976) El turismo de invierno y el asentamiento de extranjeros en la provincia de Alicante. Alicante: Diputación Provincial.

Gilbert, D., \& Clark, M. (1997). An Exploratory Examination of Urban Tourism Impact, with Reference to Residents Attitudes in the Cities of Canterbury and Guildford. Cities 14(6), 343-352.

González, M., León, C., \& Padrón, N. (2006). Obsolescencia y políticas de renovación medioambiental en el sector turístico. Cuadernos económicos de ICE 71, 153176.

Gursoy, D., Jurowski, C., \& Uysal, M. (2002). Resident Attitudes: A Structural Modeling Approach. Annals of Tourism Research 29(1), 79-105.

Gustafson, P. (2008). Transnationalism in Retirement Migration: The Case of North European Retirees in Spain. Ethnic and Racial Studies 31(3), 451-475.

Haralambopoulous, N., \& Pizam, A. (1996). Perceived impacts of tourism: The case of Samos. Annals of Tourism Research 23(3), 503-526.

Harrill, R. (2004). Residents' Attitudes toward Tourism Development: A Literature Review with Implications for Tourism Planning. Journal of Planning Literature 18(3), 251266.

Hiernaux, D. (2005). La promoción inmobiliaria y el turismo residencial: el caso mexicano. Scripta Nova. Revista Electrónica de Geografía y Ciencias Sociales, IX (194[05]) $<$ http://www.ub.es/geocrit/sn/sn-19405.htm>.

Huete, R. (2005). La imagen social del impacto del turismo sobre el medio ambiente. In Álvarez-Sousa, A. (ed.) Turismo, ocio y deporte. La Coruña: Universidade da Coruña, pp. 287-298.

Huete, R. (2009). Turistas que llegan para quedarse. Una explicación sociológica sobre la movilidad residencial. Alicante: Universidad de Alicante.

Huete, R., \& Mantecón, A. (2010). Los límites entre el turismo y la migración residencial. Una tipología. Papers. Revista de Sociología 95(3), 781-801.

Huete, R., Mantecón, A., \& Mazón, T. (2008). ¿De qué hablamos cuando hablamos de turismo residencial? Cuadernos de Turismo 22, 101-121.
Huh, C., \& Vogt, C. (2008). Changes in Residents' Attitudes toward Tourism over Time: A Cohort Analytical Approach. Journal of Travel Research 46(4), 446-455.

Johnson, J. D., Snepenger, D. J., \& Akis, S. (1994). Residents' perceptions of tourism development. Annals of Tourism Research 21(3), 629-642.

Jurdao, F. (1979). España en venta. Madrid: Ayuso.

Jurowski, C. \& Gursoy, D. (2004) Distance effects on residents' attitudes toward tourism. Annals of Tourism Research 31(2), 296-312.

Jurowski, C., Uysal M., \& Williams, D. (1997). A Theoretical Analysis of Host Community Resident Reactions to Tourism. Journal of Travel Research 36(2), 3-11.

King, B., Pizam, A., \& Milman, A. (1991). Social impacts of tourism: host perceptions. Annals of Tourism Research 20(4), 650665.

King, R. (2002). Towards a New Map of European Migration. International Journal of Population Geography 8, 89-106.

Liu, J., \& Var, T. (1986). Residents Attitudes Toward Tourism Impacts in Hawaii. Annals of Tourism Research 13(2), 193-214.

National Institute of Statistics (Instituto Nacional de Estadística) (2002) Censo de Población y Viviendas 2001. Madrid: INE.

Mansfeld, Y. (1992). Group-Differentiated Perceptions of Social Impacts Related to Tourism Development. The Professional Geographer 44(4), 377-392.

Mantecón, A. (2010). Tourist Modernisation and Social Legitimation in Spain. International Journal of Tourism Research 12(5), 617626.

Mantecón, A., \& Huete, R. (2008). The value of authenticity in residential tourism. The decision-maker's point of view. Tourist Studies 8(3), 359-376.

Mazón, T. (1987). La urbanización de la Playa de San Juan: un espacio turístico-residencial. Alicante: Instituto de Estudios Juan GilAlbert.

Mazón, T. (2006). Inquiring into Residential Tourism: the Costa Blanca case. Tourism and Hospitality Planning \& Development 3(2), 89-97.

Monfort, V.M., \& Ivars, J.A. (2001). Towards a sustained competitiveness of Spanish Tourism. In Apostolopoulos, Y., Loukissas Ph., \& Leontidou, L. (eds.) Mediterranean Tourism. Facets of socioeconomic development and cultural change. London and New York: Routledge, pp. 17-38.

Monreal, J. (ed.) (2001). Un nuevo mercado turístico: jubilados europeos en la región de Murcia. Murcia: Universidad de Murcia. 
Nigam, D., \& Kumar, V. (2009). 'India brilla' y el turismo residencial. In Mazón, T., Huete, R., \& Mantecón, A. (eds.) Turismo, urbanización y estilos de vida. Las nuevas formas de movilidad residencial. Barcelona: Icaria, pp. 209-220.

O'Reilly, K. (2003). When is a tourist? The articulation of tourism and migration in Spain's Costa del Sol. Tourist Studies 3(3), 301-317.

Pedro, A. (2006). Urbanization and Second-Home Tourism. In Buhalis, D. \& Costa, C. (eds.) Tourism Futures. Tourism Business Frontiers: consumers, products and industry. Oxford: Elsevier, pp. 85-93.

Perdue, R., Long, P., \& Allen, L. (1990). Resident Support for Tourism Development. Annals of Tourism Research 17(4), 586-599.

Pizam, A. (1978). Tourism's Impacts: The Social Costs to the Destination Community as Perceived by Its Residents. Journal of Travel Research 16(4), 8-12.

Raya, P. (ed.) (2001).Turismo residencial en Andalucía. Sevilla: Junta de Andalucía.

Ritchie, B. W., \& Inkari, M. (2006). Host community attitudes toward tourism and cultural tourism development: the case of the Lewes District, Southern England. International Journal of Tourism Research 8, 27-44.

Ryan, C., \& Montgomery, D. (1994) The Attitude of Bakewell Residents to Tourism and Issues in Community Response Tourism. Tourism Management 15(5), 358-369.

Salvà, P. (2002). Foreign Immigration and Tourism Development in Spain's Balearic Islands. In Hall, C. M., \& Williams, A. M. (eds.) Tourism and Migration. New Relationships between Production and Consumption. London: Kluwer Academic Publishers, pp. 119-134.

Smith, M., \& Krannich, R. (1998). Tourism Dependence and Resident Attitudes. Annals of Tourism Research 25(4), 783802.

Social Security General Treasury (Tesorería General de la Seguridad Social) (2009) Informe estadístico. Provincia de Alicante. Alicante: Dirección Provincial de la Tesorería General de la Seguridad Social.
Teye, V., Sönmez, S. F., \& Sirakaya, E. (2002). Residents' Attitudes Toward Tourism Development. Annals of Tourism Research 29(3), 668-688.

Tosun, C. (2002). Host perceptions of impacts: A Comparative Tourism Study. Annals of Tourism Research 29(1), 231-253.

Valencian Institute of Statistics (2008) Oferta turística municipal y comarcal, 2008. Online http://www.comunidadvalenciana.org/pdf/oferta_municpal_2008.p df

Vargas, A., Plaza, M. A., \& Porras, N. C. (2009). Understanding Residents' Attitudes Toward the Development of Industrial Tourism in a Former Mining Community. Journal of Travel Research 47(3), 373-387.

Vera, F. (1987). Turismo y urbanización en el litoral alicantino. Alicante: Instituto de Estudios Juan Gil-Albert.

Vera, F. (1990). Turismo y territorio en el litoral mediterráneo español. Estudios Territoriales 32, 81-110.

Vera, F. (1995). Programa de revitalización de municipios con turismo residencial (MUNRES). Alicante: Diputación Provincial.

Vera, F. (2005). El auge de la función residencial en destinos turísticos del litoral mediterráneo: entre el crecimiento y la renovación. Papers de Turisme 37/38, 95-114.

Vera, F. \& Ivars, J. A. (2003). Measuring Sustainability in a Mass Tourist Destination: Pressures, Perceptions and Policy Responses in Torrevieja, Spain. Journal of Sustainable Tourism 11(2/3), 181-203.

Vera, F., \& Marchena, M. (1996). El modelo turístico español: perspectiva económica y territorial. In Pedreño, A. (ed.) Introducción a la economía del turismo en España. Madrid: Civitas, pp. 327-364.

Visser, G. (2004). Second Homes: Reflections on an Unexplored Phenomenon in South Africa. Current Issues in Tourism 9(4/5), 351-383.

Williams, A. M., King, R., Warnes, A. M., \& Patterson, G. (2000). Tourism and international retirement migration: new forms of an old relationship in southern Europe. Tourism Geographies 2(1), 28-49. 